Journal of

\title{
Forest and Livelihood
}

\section{Improving Forest Governance Through} Critical Action Research (CAR): Lesson from ForestAction Nepal's Experience

\author{
Hemant R. Ojha* \\ * SouthAsia Institute for Advanced Studies and ForestAction Nepal
}

\section{Editors}

Hari Dhungana

Hari Sharan Luintel

Rahul Karki

Design ad Layout

Arjun Gyanwali

(C)ForestAction Nepal

Email: fa@forestaction.org; Web site: www.forestaction.org 


\title{
Improving Forest Governance through Critical Action Research (CAR): Lessons from ForestAction Nepal's Experience ${ }^{1}$
}

\author{
- Hemant $R$ Ojba*
}

* SouthAsia Institute for Advanced Studies and ForestAction Nepal Corresponding author: ojhahemant1@gmail.com

\begin{abstract}
The article makes the case that civil society activism should not be confined to pure advocacy of particular interests in a social segment; there is equally a role for critical action researchers to unravel a broad spectrum of exercise of power and to challenge the unquestioned acceptance of the order by the marginalized communities. The Critical Action Research (CAR) approach developed and used at ForestAction Nepal emphasizes empowering right holder citizens and their alliances through sharing knowledge that counters the dominant knowledge system, collating and communicating critical evidence for transforming policy dialogues, and learning from practice. The CAR attempts of ForestAction have generated valuable evidence of the prospects of civic organizations to act as producers of counter-knowledge rather than reproducers and disseminators of hegemonic knowledge systems that sustain exclusion, domination, and inequities. However, there are formidable challenges in trying to organize critical and engaged action research - from building up of a competent team to confronting institutional powers and raising funds to sustain the activity. It is clearly established that civil society actors have to think and act differently to understand what changes they want to bring about and how to do so.

Key word: critical action research, counter knowledge, intellectual activism, governance, knowledge hegemony
\end{abstract}

\section{INTRODUCTION}

The idea of 'transforming governance' gained prominence in Nepal especially after the 1990 political change. This change also offered an important constitutionally defined space for non-state, non-governmental, and citizen-led interventions in improving political institutions and governance practices, which were mostly inherited from the previous undemocratic political regimes. Although community action and associational forms of social life have always been a part of Nepalese society, the post-1990 situation heralded more modernist and more assertive forms of civic action: civil society organizations (CSOs) that undertake development functions and advocacy, community associations and federations, research groups, agenda based multi-stakeholder forums, issue focused social movements and campaigns, and mass movements for democracy and human rights. Despite major strides made through these civic actions on important fronts of social and political change, including the nagarik andolan (citizen movement) of 2006, a silent but perhaps more fundamental way citizen action has emerged and contributed to political change is around the practice of what I shall term Critical Action Research (CAR).

This paper describes an example of undertaking CAR in Nepal, with a view to engage with the process of improving forest governance - a sector of governance in which the state is a powerful landlord (with over $90 \%$ of forestland under government ownership). The CAR

I acknowledge the comments and inputs on the draft from Naya Sharma, Frank Fisher, Dil Khatri, Robert Fisher, Celayne Heaton Shrestha, Fraser Sudgen, Mani Banjade, Fraser Sudgen, and Krishna Shrestha. 
approach ForestAction Nepal (FA) developed emphasizes learning from practice and collating and communicating critical evidence for transforming policy dialogues, while also empowering right holder citizens and their alliances through sharing knowledge counteracting the dominant system. The approach utilized the opportunities in the apolitical space within civil society [as conceptualized by (Shrestha and Adhikari 2010)] in the post 1990 multi-party democratic system in Nepal, but still engaged explicitly with the rules, policies and laws related to forest governance that are rooted in politics.

The approach described here involves a) an organizational form created by citizens concerned with the issues of governance in the forest and natural resource sector in Nepal, combined with b) persistent efforts to create critical knowledge and catalyze innovative actions, and c) a clear alignment of research with the goal of inspiring robust social movement and meaningful community participation in political deliberations. As such, the approach discussed here is different from the dominant civil society actions in Nepal, as the latter emphasize advocacy of interests, delivery of development services, and the mechanistic and uncritical project focused engagement of International NonGovernmental Organizations (INGOs).

In this paper, I reflect upon the experience of 10 years (from mid-2000 to mid-2011) of my engagement with $\mathrm{FA}$ - a non-governmental organization (NGO), adopting the CAR approach in Nepal's forest and natural resource governance. This work has been largely oriented to democratizing forest governance and empowering local communities to take control of and manage forest resources that were historically controlled by government institutions. This was attempted through the creation of counter-knowledge in the forest governance discourse dominated by state- centric management, and strict conservation thinking, often at the cost of local communities' stakes and livelihoods. Our approach sought first to generate alternative explanations to socio-ecological issues, and then to catalyze citizen-focused innovations through strengthening community based resource management. We also acted upon multiple levels of forest governance by bringing evidence from the ground to district and national level policy deliberations, while at the same time advising community rights movements through critical evidence and strategic analysis.

My experience with FA encompasses all key responsibilities within the organization founding, leading, coordinating, directing, advising, and finally chairing the board - over the lifespan of 10 years. Since September 2011, I have not taken any formal management or leadership roles, with the intention of engaging in critical review, reflections, and research into FA's approach to civic engagement in retrospect. This paper is based on the reflections of my experience at FA and on continuing conversations with colleagues within and around this organization over the past decade. I believe that the FA experience is rich and diverse when viewed from the lens of civic activism, and in some sense, unique among the modalities of NGOs (such as those focusing on service delivery or rights movement) in Nepal. The approach to civic action in Nepal is also particularly interesting, as the forest sector in which FA work was focused primarily is one of the most centralized systems of governance in the country. Following its motto of 'critical science for democracy', FA has made significant analytical contributions to constructive policy dialogues among multiple forest stakeholders to find ways toward democratic, equitable, and sustainable forest governance in Nepal.

FA's experience evolved over time and the actors of the organization had to adjust with shifting and emerging 'political opportunity' (Tarrow 
1996) for collective civic action, particularly the constitutional rights to self-organization and freedom of expression, and the flow of international development and conservation funding. - We also had to question FA's relationship with the development funding world that tends to see local civic actions as a development NGO. For instance, FA has critically engaged with donors who tend to view organized civic action merely as a service provider - in which a donor asks an NGO to deliver service as per the contract specified by the donor. We have also tried to keep FA away from becoming an advocacy organization itself. Instead, we support networks of local people advocate on their own behalf. We also emphasize research, and exploring new methods of researching, in that contributes to the local change process and questions the larger discourses shaping local practices. We deliberately avoid common pitfalls of researchers. First, we consider research outputs linearly feeding into the policy system rather than becoming traditional academic researchers, who see research and policy as two different systems. We also strive to go beyond disciplinary boundaries in framing research and action, as we were very clear from the outset that a disciplinary focus would prevent us from seeing the reality and engaging practically in the learning processes. In order to organize such critical and learning focused engagement, we also had to experiment and innovate with a more interactive and flatter organizational framework than is commonly found in the formally organized NGOs.

In writing this paper, my hope is that a careful reflection upon a decade long experience in this field will make some contributions to the body of knowledge about how civic actions emerge and become organized in a context of a fragile state, social inequality, and rapid environmental transitions. I would also anticipate that my story around FA can provide a framework for critical action researchers to present their work in a reflective way. Four key findings from this paper are noteworthy. First, civic actions should not ust be considered as advocacy of interests but also constructive engagement in demonstrating solutions that work. There are clear cases in which advocacy actions alone failed, but had more favorable outcomes when combined with CAR interventions. Second, the dominant neoliberal and developmentalist power and mindset tends to limit organized civic actions as contractual service providers, it is critical that organizations act as producers of counterknowledge rather than being reproducers and disseminators of current hegemonic knowledge systems that sustain exclusion, domination and inequities. Third, based on continued and determined practice of critical social science and production of counter-knowledge, it is possible for the dominant state and donor actors to become more interactive and collaborative in planning and governance process. Fourth, it reveals the adaptive approach to organization building, so as to become effective in learning from action (Fisher 2012).

The next section outlines the conceptual framework of CAR, followed by a brief description of the historical and political economic context of the forest sector in which FA and its CAR approach emerged. In the third section, I provide a few examples of how CAR actually operated at different levels and aspects of forest and natural resource governance. The fourth section identifies and analyzes several frontiers of CAR engagement and challenges that the leaders and innovators of CAR have to face. I will then conclude with some key insights and lessons of wider relevance.

Methodologically, this account can be seen as a combination of auto-biographical and autoethnographic methods, informed by critical social science perspectives, although I did not use these in a fully conscious way from the beginning of my work. It is more of a 
retrospective analysis from these perspectives, advance policy debates at district and national drawing on a number of previous analyses of levels.

various aspects of CAR (McDougall et al. 2007; Ojha 2008; Ojha et al. 2008; McDougall et al. 2009; Ojha 2009).

CONSTRUCTING THE MEANING OF CRITICAL ACTION RESEARCH (CAR)

FA was not created to implement something called critical action research (CAR) that was out there already. Rather, it is through the experience of FA over time that the CAR approach evolved. FA and its CAR approach co-evolved through action and reflection processes over the years - conducting dozens of small action research projects in about 15 districts and several dozen villages. Right from the beginning, we were concerned with the dominant knowledge systems and mindsets behind the techno-bureaucratic, top-down, state-centric governance of forest and natural resources. But we were also aware of our own limits of working as a formal organization, not directly dependent on natural resources for livelihoods, and external funding of our work. Our CAR approach evolved as we worked with selected community forest user groups (CFUGs), which are registered at local District Forest Office as legitimate manager of the designated forest patch, as per the Forest Act 1993. Our approach embraced multi-level engagement as we moved up from local communities to district stakeholders and national policy makers. We tried to dig out the roots of persistant inequity and exclusion at CFUG level, and to explore the aspirations of disadvantaged groups at the community level. We compiled evidence for counter-knowledge from the field and also strengthened local community groups in better and more equitable management of forests. These experimental works - with varying levels of successes and failures provided critical knowledge resource to

As part of organizing diverse collaborative activities with donors and international organizations (on which FA has to rely for funding and to some extent learn what is happening outside), we of course used a number of phrases offered by our collaborators in different times - such as action research, action learning, participatory action research, adaptive management, social learning - linked with various research and action projects we undertook over the past 10 years ${ }^{2}$. But as we were able to exercise some choice over which partners we would like to work with and how, many of these phrases had some common threads that eventually constituted CAR. In particular, the following research works helped FA develop and refine its CAR approach:

a) Participatory action research on community forest user groups conducted in collaboration with University of Reading (2001-04).

b) Adaptive collaborative management research conducted in collaboration with Centre for International Forestry Research (CIFOR) and with support from Asian Development Bank (ADB) and International Development Research Center (IDRC) al:(2002-07).

c) Knowledge systems and natural resources management research in which we studied how actors learn natural resource management (with support from IDRC) (2003-05)

What exactly is CAR in the life and functioning of FA then? Let me first define its three parts and then sum it up together:

- The approach is critical: Here, we drew inspiration from critical social science literature that social research is not a politically neutral act. We therefore focused our work on generating counter knowledge. This

For a detailed description of this, see Banjade (2012). 
closely resonates with unraveling hegemony through critical inquiry and discourse in Gramsci's sense (Gramsci 1990). We believed that hegemonic formations and practices of forest governance could be challenged and questioned in the domain of civil society and in the realms of knowledge, discourses, and practices. This also resonated with Habermas' formulation of critical theory as an endeavor to unpack 'systematically distorted communication' in society (Habermas 1970). In Pierre Bourdieu's language, this is about critiquing symbolic violence by questioning the unquestioned beliefs (doxa) and also creating an 'epistemological break' (Bourdieu et al. 1991) with the primary experience of the people by accepting the established order.

- The approach is action-oriented: At FA, we were also inspired by Kurt Lewin's view- You cannot understand a system, unless you try to change it" (Lewin 1951). Professionals and researchers can do excellent and critical research to diagnose the problem, but they may remain disengaged with the particular communities or societies in which such studies are done. We embraced the Lewinian view that without an orientation to change and a preparedness to capture the effects of interventions, we cannot fully understand the complexity of natural resource governance and practices in Nepal. Thus, to remain action-oriented means not only to accept obligations to contribute to changing society at large while doing research, but also being able to grasp the difficulty and uncertainty involved in the process of change. This also requires the researchers to transcend the disciplinary and institutional boundary so that they can frame the research to address the practical concerns of the people, even though it may not perfectly fit with the disciplinary frames of the researchers. The action orientation and interaction with communities in our approach makes it clear right from the beginning that whatever we advocate should emerge from the con- crete experience/experimentation of the real world. Through such processes both the evidence and the empowerment of human agents to carry forward the evidence in political articulation is important. At the time we founded FA, there was more noise than grounded voice on rights and empowerment. We found that many of the radical and critical explanations put forth against the dominant technocratic approach by advocacy groups and their allies were not making sense in the debates of change unless they were founded with some actions, evidence and reflections. This formed an immediate social context for the development of CAR approach in Nepal's forest sector.

- The approach is research-and learningoriented: We emphasized creating new knowledge for change rather than doing business-as-usual development. At times we disappointed some communities, as there were few intervention outcomes as we focused more on collating evidence and communicating it to the wider public sphere. Our belief, however, is that some of the local problems people face are simply the manifestations of national level problems. The other aspect of learning was about discovering and questioning our own mental models. We always tried to remain inquisitive and were prepared to challenge our own assumptions. One of our conclusions is that policy and practices in forestry are guided by a lot of accepted beliefs and standard frameworks nurtured and inherited from the past, and there is a need to foster organized production of counter knowledge. However, our position as an NGO at times provided flexibility in undertaking research in ways we liked to do, but also left the research with limited take up by the government, parliament, and other decision makers. To enhance research uptake, we had to engage a diverse range of stakeholders in the process from research design through to policy communication. How FA's approach evolved in relation to these multiple 
challenges of Nepal's forestry sector is outlined in the next section. One of the key research innovations is that our research does not end with producing some facts. Rather, we tried to build a system of communicating our research to the intended audience that would include not just policy makers, but more importantly the actors in the social movement.

While we emphasize CAR as the central theory of learning and change within FA, not all of the activities FA did or does are essentially part of a larger strategy of CAR. This is in part a reflection of the freedom of actors within FA, which is comprised of individuals with varying degrees of inclination and attachment to discursive action and the research aspects of CAR. There is no branding mechanism of CAR to certify that the activity has met the standards of CAR. Nevertheless, every action is subjected to some level of CAR related reflections and analysis as part of regular sharing within the FA team. From the beginning, there was in place a regular system of reflection and sharing involving several elements of CAR, which later on came out more systematically and rigorously within the organization. Similarly, we identified and engaged with "change agents" - individuals with greater commitment to change - from different organizations into a collaborative learning process in order to develop shared understanding and ownership of action and research outcomes. This has helped incorporate outsiders' views and suggestions in different CAR cycles, which were facilitated by FA.

\section{CONTEXTUAL ROOTS FOR THE}

\section{EMERGENCE OF CAR IN FORESTRY} SECTOR

The agrarian and pre-capitalist nature of Nepal's economy hinges primarily on natural resources, with tenure, governance, and market linkages as central issues. It was the conviction that social exclusion and injustice are deeply rooted in unequal access to, and control over, natural resources that inspired the founding of $\mathrm{FA}$ in 2000. The founders of FA, building on experience in and analysis of Nepal's political economy, strategically targeted the forest sector because of its significance to local livelihoods, politics, and wider environmental concerns. Our choice of forestry was also based in part on our prior experience in this sector. The intention of FA was to use research and policy advocacy to catalyze critical thinking and democratic innovation in forest governance. In the post 1990 environment of the multi-party liberal democratic system, civil society activity grew profusely in Nepal. This growth included proactively taking a significant role in the community forestry movement and forest sector as a whole.

At a time when we were conceiving the organization of FA, there was a tension in the forest sector about whether to promote community based management or undertake scientific forest management by the government itself. Bilateral donor projects in forestry helped shape new forest legislation 1993 (implemented since 1995) that empowered civil society leaders to demand devolution of forest rights to local communities, in the context of post-1990 multi-party democratic environment. But we observed that, despite formal and rhetorical changes in legislation and the development of participatory and community based resource management innovations, the actual system of forest governance remained entrenched within the historical techno-bureaucratic institutional systems. Nascent participatory innovations and increasing demand for upscaling of community based forest management systems were obviously waiting for a national player that could link local practices with national policy debates in more reflective, critical, and socialscientific manner.

The process of devolution in forestry was neither quick nor easy, and by 2000 there was a clear gap for the role of a CAR organization. 
Since the creation of the Department of Forest in 1925, the state consistently expanded its control of forests through a series of legislations ${ }^{i}$, that enforces effective national control over forests by expanding the forest bureaucracy and excluding local people. In 1957, the state-centric efforts to control and manage forests culminated with the nationalization of private forests, in which the bureaucracy assumed the role of managers as well as technical experts. The 1957 nationalization act assumed that taking forests from private groups and entrusting them to the state would enhance people's access to resources, as local people were seen as destroying forests through unsustainable use. Panchavat era forest legislation even allowed forest officials to shoot people on sight if found collecting forest products. In effect, the state created a strong techno-bureaucratic field by instituting stringent regulations to exclude people from the role of forest management (Ojha 2006).

Despite some changes in attitude and behavior of forest officials towards working with people, largely as a result of the community forestry movement in the hills, the orthodox attitude of state-centric scientific forest management has endured. This has left a crucial gap for efforts that reveal deeper power relations and hegemonic knowledge systems that lie on the road to greater justice and the empowerment of local people, and formed an important context for our CAR approach.. to fill in the forest sector. We felt compelled to reveal these hegemonic exercises of power and also to offer forums for critical and deliberative engagement among citizens, officials, and other actors.

The agenda of participatory governance emerged when there was a crisis in technobureaucratic confidence during the seventies, triggered by the news of Himalayan degradation ${ }^{\mathrm{ii}}$ (Eckholm 1976). Nepal's strategic geopolitical situation and fragile environmental condition attracted bi- and multilateral donors, who took forestry and environment as key elements of integrated conservation and development projects. Donor pressure on explicit government commitment towards decentralisation was also growing, and was becoming a part of aid negotiation ${ }^{3}$. But the donor led development in forestry was also meeting a point of saturation when we started FA, and this itself became a key area of FA's CAR engagement (see later). In the post-1990 environment, the bilateral donor forestry projects that had their own implementing structures were facing demands for institutional change towards greater participation of local organizations, NGOs, and communities. FA's emergence was seen as a threat by those involved in conventional approaches to service delivery through donor created project units. Our strategy was to look out for international competitive resources rather than getting engaged with resource politics, in which we succeeded to a significant extent.

As the number of registered community forestry user groups multiplied across the country, Nepal also moved through periods of conflict and political turmoil, especially after Maoists declared the 'People's War' in 1996. One of the claims on which Maoists based their war was that multi-party democracy and international development were both responsible for social exclusion in Nepal. They saw the community forestry program as reproducing the same problems, although local communities remained resilient throughout the civil war and continued to function without much interruption (Karna et al. 2010). Maoists believed that the issues of exclusion were more systemic, historic, and rooted in larger political structure, all justifying the need for 'revolution'. This created ground

For elaborate discussion on how aid contributed to change and reproduction of forestry sector, please refer to another paper Ojha (forthcoming) in book edited by Thompson and Gyawali. 
for CAR to explore and catalyze inclusive and been able to come to genuinely 'public' spheres, equitable governance of forest resources in the let alone the 'subaltern' public sphere, and are country, eventually addressing the very rather confined to small-scale, instrumental foundations giving rise to violent conflicts. domain of "projects" and resource networks. Clearly, we wanted to develop an approach to In some cases, leaders from the local engage people and stakeholders to rethink community and larger civil society have formed existing institutions, policies, and practices for collusions with corrupt groups within the fairer distributional outcomes and equity, going government and illegal timber traders, therefore beyond both confrontational strategies adopted creating challenges in decentralized governance. by rights activists and apolitical and project- This means that natural resource governance is centered strategies adopted by INGOs in problematic not solely due to technoNepal.

Still another contextual concern that inspired our CAR approach was the lack of opportunities for people to influence policy despite the rhetoric of democracy (Ojha et al. 2007). Within the policy sphere, political leaders continued to be guided more by the "administrative will" of the respective line ministries rather than by "public will" (as stressed in the ideal of deliberative democracy). This was partly because of the collusion of the private interests of the political leaders and bureaucrats, and partly because of the liberal democratic mindset in which elections without adequate deliberative links between citizens and leaders entitles representatives to make decisions on behalf of the larger mass of people. In such contexts, we have always remained intellectually curious and practically engaged to the way both radical and democratically elected leaders easily fall prey to the bureaucratic rationality once they come to the government. CAR thinking was therefore animated by fundamental concerns over governance failure that needed more concrete learning and analysis and not just advocacy.

While we sought to expand public sphere of dialogues and participation, we have also remained critical of the populist posturing and weakening the state. Our understanding is that despite the proliferation of NGOs, associations, and federations, civil society actors have not yet problematic not solely due to techno-
bureaucratic dominance, unaccountable politics and donor-driven programs, but equally due to the problems within civil society itself. Our work at FA has therefore been equally motivated by the urge to understand, catalyze, and transform how civil actors can engage in the process of governance reform, including demonstrating an innovative strategy of civic action itself.

Within the existing landscape of actors in forest governance, our approach was critical as well as balancing. We also avoided making sweeping classifications of actors as progressive or regressive; rather we believed and actively pursued the difference within each institutional category. For instance, while we criticized the dominant tendency of a top-down technobureaucratic mindset within Ministry of Forest and Soil Conservation, we identified and built alliances with several progressive, critically engaged, and change-oriented forestry officials who have been fighting for change from within the system. Likewise, we did not seek to establish close relationships with any particular political party, but sought to engage equally with groups associated with all major parties (though our engagement with political leaders has been mostly through community federations on forest, drinking water, irrigation and others, which we have been supporting through CAR based evidence and strategic advice).

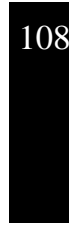




\section{HOW DOES CAR HAPPEN?}

Our work at FA, as outlined earlier, involves multiple actions and research from local to national domains. Table 1 below identifies how the CAR related interventions of FA have

Table 1: CAR interventions in forest policy

\begin{tabular}{|l|l|l|l|}
\hline Policy Issues & \multicolumn{1}{|c|}{ Level } & ForestAction Contribution & Achievement \\
\hline $\begin{array}{l}\text { Special forest policy } \\
\text { for Terai (April 2000) } \\
\text { and wider debate of } \\
\begin{array}{l}\text { Terai forest } \\
\text { Governance }\end{array}\end{array}$ & Policy & $\begin{array}{l}\text { Action researches } \\
\text { Dissertations book } \\
\text { journal articles special } \\
\text { issue of journal on } \\
\text { Terai forest }\end{array}$ & $\begin{array}{l}\text { Reframe and } \\
\text { decentralize terai } \\
\text { forest governance } \\
\text { debate }\end{array}$ \\
\hline $\begin{array}{l}\text { Community } \\
\text { Forestry }\end{array}$ & Guidelines & $\begin{array}{l}\text { Actively participated in } \\
\text { taskforce analysis and } \\
\text { papers Focusing pro-poor } \\
\text { and inclusive provisions }\end{array}$ & $\begin{array}{l}\text { Pro-poor CF } \\
\text { guidelines }\end{array}$ \\
\hline $\begin{array}{l}\text { Forest Act amendment } \\
\text { (different attempts } \\
\text { including 2001, 2010) }\end{array}$ & Act & $\begin{array}{l}\text { Field study } \\
\text { Discussion paper } \\
\text { Policy roundtable }\end{array}$ & $\begin{array}{l}\text { Government } \\
\text { withdre } \\
\text { amendment bill }\end{array}$ \\
\hline $\begin{array}{l}\text { Gaurisankhar } \\
\text { Conservation Area } \\
\text { (2010- 2011) }\end{array}$ & Regulations & $\begin{array}{l}\text { Field study } \\
\text { Policy roundtabel }\end{array}$ & $\begin{array}{l}\text { Ensured } \\
\text { community rights } \\
\text { in Gaurisankhar Ca } \\
\text { regulations with }\end{array}$ \\
\hline $\begin{array}{l}\text { CF inventory } \\
\text { guidelines (September } \\
\text { 2000) }\end{array}$ & Guidelines & $\begin{array}{l}\text { Field study and report } \\
\text { Review article in JFL }\end{array}$ & $\begin{array}{l}\text { Simplified CF } \\
\text { inventory } \\
\text { guidelines }\end{array}$ \\
\hline
\end{tabular}

Source: Paudel and Ojba (2011)

Few examples can illustrate how we organized CAR in response to different issues of forest and natural resource management and governance.

Example 1. Problematizing the universality of science and opening up spaces for public debate around issues that were earlier closed as being scientific. Nepal's forestry sector historically was a bounded policy-making formation, with a top-down and centralized

decision-making. Although the elected parliament endorsed the progressive Forest Act 1993, recognizing local communities as the managers and users of local forests, the legacy of the government departments considerably distorted the intention of the legal change. These distortions were effected through the formulation of new regulations or bylaws, directives, guidelines and official circulars that together undermined the participatory essence of the Act. One of them was the Forest 
Inventory Guidelines 2000, which imposed a complicated, 'scientific' method of forest measurement to local community forest user groups (CFUGs) as a pre-condition for signing and renewing forest management agreements. The Guideline was issued without the consultation of CFUGs and civil society groups. This created country-wide havoc as District Forest Officers began suspending agreements with local CFUGs invoking the lack of inventory/measurement data as required by the new Guidelines.

FA worked with the Federation of Community Forestry User Groups, Nepal (FECOFUN) and NGOs to understand the scale and complexity of the problem at the ground level. We recognized that it was necessary to further probe the issue and to propose alternative ideas on how science and local knowledge can be combined to inform forest management decision-making, and how that can be reflected in the national policy. FA produced a policy discussion note entitled "science and politics of forest inventory in Nepal" in 2002 (Ojha 2002) and shared it with policy makers, donors, researchers and activists nationally and to international networks. A survey of the problems facing CFUGs across Nepal was done and a report was produced (Dhital et al. 2002). FA researchers made field visits to understand community perspectives on the Guidelines and held interactive meetings with forest officials at different levels. Articles and opinions from diverse stakeholders, including the research conducted by FA, were collected and disseminated through various Issues of the Nepali language journal of FA - Hamro Ban Sampada. The inventory issue was also identified as a case study in another research on Knowledge Systems of FA (Paudel and Ojha 2008) and was further analyzed and published (Hull et al. 2010). These analyses generated options for reconciling scientific forestry with local knowledge.
Our analytical insights and evidence stimulated new thinking and realization on the part of policy makers, and stronger community voice demanding user-friendly Guidelines. The evidence we generated was compelling, and it was recognized that the Guidelines had become overbearing to local people and was contrary to overall policy. Eventually, in 2004, the Director General of the Forest Department initiated the process of revising the Guidelines, this time forming a multi-stakeholder task force, to conduct a series of consultation meetings with stakeholders. FA contributed directly to the discussions, analyzed the processes of policy negotiation, and provided critical suggestions on how scientific and local knowledge can be combined into a framework of democratic forest governance.

Example 2. CAR to transform patron-client relations between forest bureaucracy and local communities. During 2004-6, a team of researchers worked with Chautari CFUG in Morang district, as part of FA's multilevel action research initiative. This case demonstrates how critical action researchers were able to empower the CFUG members to have deliberative engagement with the forestry officials on better utilization of forest products. Although the community forest was formally handed over to the CFUG, the actual decisions on forest management were still controlled by the District Forest Office (DFO). Surprisingly, the issue of everyday forest access had not yet become the priority agenda of national level FECOFUN, as it was articulating other policy agendas at national and international levels. A team of FA researchers visited the site as part of their CAR intervention. They spent several months questioning and challenging the villagers to make them more conscious about inquiring, probing, reflecting and discussing issues at hamlet and village levels, as well as with other stakeholders. The deliberative processes helped to improve the confidence of users as legitimate managers of forest to make sense of the legal documents, better understand the technical calculations and 
terms used in the forest management plan document (through which forest officials were manipulating the harvesting practices) (Ojha $e t$ al. 2010). This also allowed FA researchers to collect and organize evidence in relation to the problems of local institutions, and thus enabled them to challenge the techno-bureaucratic domination in the language of science itself.

Likewise, during the same period, the team worked with Handikharka CFUG in Dhankuta district. Here, researchers were able to encourage critical self-reflexivity among the CFUG elites who were ill-advised by the forest officials to adopt a protectionist approach to forest management that excluded disadvantaged groups. In this case, CAR interventions focused on providing equitable access to forest products by promoting firewood production against the conventional timber forestry and protectionist wisdom held by techno-bureaucratic control. A similar work earlier in Kavre district emphasized deliberative empowerment (Banjade and Ojha 2005). Here, FA researchers worked with different subgroups within Karmapunya CFUG, and challenged their fatalistic conceptions in relation to their participation in forest control and use. Unlike 'extension' or training, our team engaged with critical dialogue and provided information on political rights, which sparked more active engagement of disadvantaged and marginalized groups in the CFUG process, eventually improving governance and equity in sharing benefits from the forest. ':More evidence and lessons in this regard have also documented elsewhere by FA's professionals (Luintel 2006, Timsina et al. 2004)
Example 3. Questioning non-deliberative and strategically framed policy and program initiatives and then expanding public debate. A key area of hegemony we encountered in Nepal's forestry sector concerns the way donor money is channeled for the benefit of local communities. As mentioned earlier, various donors generously funded forestry development in Nepal, including setting up of the community forestry system. Over the years, the project structures themselves began to emerge as durable organizations in the institutional vacuum between donors and government. At the end of year 2009, as the two bilateral projects were coming to end, the project staff were trying to find out ways to create and manage projects to be funded by donors. They engaged a few Ministry of Forest and Soil Conservation(MoFSC) officials to undertake an evaluation of community forestry impact focusing on their project sites. Though it was packaged as an independent evaluation of CF system, we were aware that the study was being driven to establish the legitimacy of continued funding of the projects, rather than open up discussion for better aid governance to reach out local people. FA drafted a letter outlining key aspects of concerns and also providing suggestions, and was submitted to the Secretary of the Ministry of Forest and Soil Conservation (see Box 1 below). Questions were raised about several fundamental aspects of the study governance: who defined the agenda, what was the scope of the study, and what were the methodological assumptions masking the strategic interests of those framing the study?

Box 1. ForestAction Concerns and Suggestions on the Community Forestry Impact Evaluation Study

Excerpts of a letter sent by the head of ForestAction Nepal to the Secretary, Ministry of Forest and Soil Conservation on December 24, 2009.

Concern 1 . Who defined the evaluation agenda?

It appears that although the call has been formally announced (December 11, 2009) by the Ministry of Forest and Soil Conservation (MoFSC), there is a "core group of stakeholders" 
which seems to be initiating the study process. It is not clear who these core group of stakeholders are. There is a suspicion among forestry sector civil society that this process excludes several key players of CF in Nepal. FA as a key research player in Nepal's community forestry is not aware of any processes that led to this call.

Also, the Call further stipulates that MoFSC announces the Call on behalf of "task force", but it is not clear what kind of task force is this, who constituted it, and how. Since we do not know who is within the Task Force, we fear that this has exacerbated the sense of exclusion among many important players of CF in Nepal. We are really surprised to know why the apex level government body like MoFSC is working "on behalf of the task force" that is not transparent to wider society.

Suggestion. The history of CF development in Nepal is uniquely participatory compared to other sectors. So we suggest we retain this historical strength of $\mathrm{CF}$ when it comes to $\mathrm{CF}$ evaluation as well. This approach will ensure wider uptake of evaluation findings, and trigger constructive engagement among diverse stakeholders of CF in Nepal, thus leading to change we all anticipate. We suggest the following actions for the MoFSC in this regards:

- Revive the Forestry Sector Coordination Committee (FSCC) with inclusive civil society representation, and convene FSCC meeting to discuss the need for impact evaluation as part of forest sector reform agenda. The FSCC meeting may constitute a task force for various key tasks to be undertaken, including the impact study.

- Entrust Community Forestry Division (CFD) within the Department of Forest with key focal point role instead of donor program. CFD should act as the secretariat of the impact evaluation steering committee or task force formed by FSCC. This is because the Division is the central government unit to coordinate community forestry activities, manage CF database and provide feedback to policy.

Concern 2. Scope and objectives of the impact study.

The impact study mainly seeks "to assess the extent to which community forestry has contributed or not to livelihood benefits". Our view is that we should not commission evaluation research simply to find "yes or no" answer to this question, as it would simply tell us whether we should continue the programme or not. Instead, our enquiry should be aimed at identifying the useful lessons for enhancing the performance of $\mathrm{CF}$ in order to address the multiple economic, social and environmental challenges. In particular, we need to understand which intervention modalities have generated what kinds of outcomes in different contexts. If we want to use the study findings to design future programs, then we need to focus on modalities, inputs and strategies of various CF support programs as the key variables of analysis. More importantly, we need to recognize that it is actually the communities themselves that have spent at least four times more investment than the donor or government in forest management. It will be unfair if we see community forestry primarily as a donor funded activity, and undervalue the millions of dollar equivalent cash and in-kind investment made by over 10 million people affiliated with community forestry in Nepal. The idea of evaluation should be to understand how public spending can further enhance the existing struggles and initiatives of local communities, local citizen groups, women and disadvantaged groups, rather than justify or reject particular donor or government programme modality. 
This means that we need to review not only DFID and SDC supported activities, but also include samples of other CF projects and support activities implemented by INGOs, NGOs, CBOs and community networks, in a comparative framework so that we can arrive at most effective intervention modalities.

Suggestions:

- Reframe evaluation objectives to examine the impact of various modalities of CF (actors, strategies, processes) and the linkages/conflicts/synergy between CF and other modalities of community based forest management - particularly leasehold forestry and collaborative forest management.

- Design the study to evaluate the comparative effectiveness of public spending (govern ment budget, donor funds) in support of creating sustained livelihood opportunities, economic innovations and transforming governance.

- Focus on understanding the endogenous, local and citizen-led processes and initiatives for change and transformation rather than the processes driven by donors, central government and other national institutions....

\section{Concern 3. Methodology}

Methodology of the impact evaluation is the most important part, and should be clearly linked to the evaluation objectives (for which we provided suggestions in the previous section). Since we need to reframe the objectives, we need to revisit methodology accordingly. Currently, the design is silent on the issue of attribution. While qualitative case studies can provide deeper insights, we should focus more on quantitative analyses. There are already plenty of case studies which can be reviewed, and any need for fresh case studies should be determined only through careful review of what already exists.

\section{Suggestions}

- Expand the scope of survey beyond assessing "what livelihood impacts have occurred" to include what intervention modalities have created this, under what contexts, and with what dynamics of innovation generation processes.

- Since in-depth qualitative case studies are likely to be strategically manipulated, focus should be on quantitative analysis. Variables for quantitative analyses should be carefully devised from the objectives and key questions for evaluation.

- A team of experts should be asked to advise on the sampling frame which need to be agreed by the multi-stakeholder group or task force formed by FSCC.

- The review should be linked to the learning questions and challenges experienced by FSCC, and should contribute to the ongoing learning among forest stakeholders.

Source: FA (2009)

This eroded the legitimacy and enthusiasm of the study process, but could not entirely withdraw the study. Our strategy in this case was limited to questioning and not so much empowering the affected groups to actively oppose the process. 
Example 4. Creating multi-stakebolder management, forest based enterprise, and dialogues and policy forums. Since 2009, FA protected areas and green economy. The has run a regular policy forum, called Ban Executive Coordinatoriii of FA claims that: Chautari, in which it has collaborated with the association of foresters and federations of community forest groups. Unlike conventional policy forums, the Ban Chautari model involves sequential combination of diagnostic analysis of emerging policy issues by researchers, empowerment of disadvantaged groups concerned with the policy issues, holding multistakeholder policy dialogues, and wider dissemination of the research outcomes and deliberative processes to the public.

In 2011, we conducted nine Ban Chautaris on issues covering forest act amendment,

sustainable forest management, timber

"The process has made some good achievements. First, the initiative has institutionalized Ban Chautari- a unique process of policy dialogue that combines diagnostic analysis with structured policy dialogue. Second, it has provided a welcoming environment for dialogue where people can share their views without any fear, which has also helped develop trust among the stakeholders. Third, it has been able to narrow down the gaps in stakeholders' understanding of some major contentious policy agenda such as sustainable forest and timber management and protected area governance."

Table 2: Summary of policy contribution of Ban Chautaris

\begin{tabular}{|c|c|c|}
\hline Topic & Policy issue & Contribution from Ban Chautari \\
\hline $\begin{array}{l}\text { Revisiting PA buffer } \\
\text { zones: Exploring } \\
\text { legal and } \\
\text { institutional reforms } \\
\text { in buffer zone } \\
\text { management }\end{array}$ & $\begin{array}{l}\text { After } 15 \text { years of } \\
\text { implementation of } \\
\text { buffer zone programme, } \\
\text { new challenges have } \\
\text { emerged and stakeholders } \\
\text { are demanding } \\
\text { substantial change in its } \\
\text { legal and institutional } \\
\text { framework }\end{array}$ & $\begin{array}{l}\text { Stakeholders agreed that programme needs } \\
\text { revision including its foundation law protected } \\
\text { area act } 1973 \text {. BZ council's lead role and } \\
\text { government's facilitating role suggested. }\end{array}$ \\
\hline $\begin{array}{l}\text { Restructuring } \\
\text { Protected Areas: } \\
\text { Exploring democratic } \\
\text { governance } \\
\text { framework of } \\
\text { conservation areas in } \\
\text { Nepal }\end{array}$ & $\begin{array}{l}\text { Continued expansion of } \\
\text { protected area is } \\
\text { increasingly contested, } \\
\text { deliberative and inclusive } \\
\text { process is demanded }\end{array}$ & $\begin{array}{l}\text { Role of conservation areas in managing larger } \\
\text { landscapes is appreciated. They also recognised } \\
\text { the shortcomings with existing models and saw } \\
\text { opportunities for more democratic and } \\
\text { participatory management models. }\end{array}$ \\
\hline $\begin{array}{l}\text { Poverty reduction } \\
\text { through forestry: } \\
\text { Exploring strategies } \\
\text { to realise economic } \\
\text { benefits of timber } \\
\text { management in } \\
\text { Nepal }\end{array}$ & $\begin{array}{l}\text { Timber has been kept in } \\
\text { low profile in policy } \\
\text { debate and discourse } \\
\text { despite it has been hot } \\
\text { spot in practice. This has } \\
\text { undermined the potential } \\
\text { benefit that could be } \\
\text { fetched from the Timber }\end{array}$ & $\begin{array}{l}\text { Realizing the huge potential of timber to } \\
\text { contribute in national economy and } \\
\text { employment, stakeholders called for attention to } \\
\text { bring the timber policy and associate issues in } \\
\text { public debate and policy priority. }\end{array}$ \\
\hline
\end{tabular}

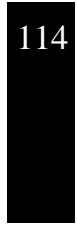




\begin{tabular}{|l|l|l|}
\hline Topic & \multicolumn{1}{|c|}{ Policy issue } & \multicolumn{1}{|c|}{ Contribution from Ban Chautari } \\
\hline $\begin{array}{l}\text { Forest Enterprise: } \\
\text { Opportunities and } \\
\text { Challenges in the } \\
\text { context of Nepal }\end{array}$ & $\begin{array}{l}\text { There are huge policy } \\
\text { gaps and practical hurdles } \\
\text { in promoting } \\
\text { community-based forest } \\
\text { enterprises. }\end{array}$ & $\begin{array}{l}\text { Key policy gaps and practical hurdles for } \\
\text { community-based forest enterprises were } \\
\text { identified and attention of government has been } \\
\text { drawn for revising the policies and correcting in } \\
\text { practice. }\end{array}$ \\
$\begin{array}{l}\text { Scientific Forest } \\
\begin{array}{l}\text { Management: } \\
\text { Opportunities, } \\
\text { Challenges and } \\
\text { Reality }\end{array}\end{array}$ & $\begin{array}{l}\text { Irrespective of } \\
\text { management regime, } \\
\text { Nepalese forest lack } \\
\text { scientific and productive } \\
\text { forest management. }\end{array}$ & $\begin{array}{l}\text { Key factors hindering to the scientific forest } \\
\text { management have been identified and } \\
\text { stakeholders called for immediate action for } \\
\text { piloting productive forest management in } \\
\text { different management regimes. }\end{array}$ \\
\hline $\begin{array}{l}\text { Nepal's Forests: } \\
\text { Green economy or } \\
\text { black money }\end{array}$ & $\begin{array}{l}\text { Despite huge potential to } \\
\text { promote green economy, } \\
\text { Nepal's forests are being } \\
\text { playground for black } \\
\text { money. }\end{array}$ & $\begin{array}{l}\text { Four key issues require consideration to move } \\
\text { towards green economy. The conceptual clarity, } \\
\text { services and technologies, policy and legal barriers } \\
\text { on forest based trade and enterprise and tenure } \\
\text { security, community rights }\end{array}$ \\
\hline $\begin{array}{l}\text { Challenges of } \\
\text { Churia conservation } \\
\text { and role of local } \\
\text { communities }\end{array}$ & $\begin{array}{l}\text { Despite huge efforts from } \\
\text { government and other } \\
\text { development agencies, } \\
\text { Churia region across the } \\
\text { country is degrading and } \\
\text { President Churia } \\
\text { Conservation program } \\
\text { initiated by Gon has } \\
\text { been highly contested. }\end{array}$ & $\begin{array}{l}\text { Stakeholders unanimously agreed that Churia } \\
\text { needs immediate attention due to ecological, } \\
\text { socio-economic and political significance. It } \\
\text { requires technological and institutional } \\
\text { innovation to deal with the current conservation } \\
\text { challenges. With this realization, the stakeholders } \\
\text { agreed to sit on further debate and discussion for } \\
\text { improvising the Present Churia Conservation } \\
\text { Program and seeking other options. }\end{array}$ \\
\hline
\end{tabular}

Source: Khatri et al. (2012).

In a recent review meeting on Ban Chautari series of dialogues, the government participants shared largely positive responses. They highly appreciated the initiative and recognized that such processes would contribute to informed policy making in forest sector FA 2012.

- The secretary of MoFSC appreciated Ban Chautari and opined that the government could have provided funding and other support for this process. He assured FA that senior officials will participate in future events provided they are informed in due time.

- A former secretary of MoFSC suggested that the government should own and support the process as it would add legitimacy to the policy process. He urged senior offi- cials to manage their time to participate in the Ban Chautaris. He also suggested for working closely with government authority to enhance the policy intake through such process.

- A joint secretary at the MoFSC opined that contrary to everyday CSO-led meetings organized to invite and then humiliate policy makers, Ban Chautari has established a culture of mutual respect and genuine exchange of ideas.

The Director General of Department of Forest (DoF) appreciated the process and opined that the DoF would benefit from such dialogues. 
Some officials also warned against potential pitfalls of externally funded initiatives. They suggested that Ban Chautari should take a nationally relevant policy agenda, maintain transparency of policy issues and management aspects, share outcomes to all relevant actors, and constructively support government in its policy process. The FA team and their collaborators welcomed these suggestions and pledged to continue with this forum for policy dialogues.

\section{CRITICAL ACTION RESEARCH:} HOW IS IT ORGANIZED?

Having outlined the CAR approach and how it can catalyze and stimulate democratization of governance at different levels, I now turn to discuss how this approach was organized by FA over the past 10 years. While organizing CAR oriented activities at FA, we engaged in at least the following 7 domains:

\section{Creating and Transforming the} Institution

Example 5. Strategic and advisory support to community federations on forest and natural resources. Significant time and energy of the FA staff has been spent providing assistance, advice, and organizing resources to strengthen the activities of federations of community based resource management groups. FA is invited by these federations regularly to their strategic meetings and internal reviews. FA staff provides a broader analysis of issues confronted by these federations. Engagement with such community-led federations has enabled FA to directly share its research findings with the public and concerned citizen community, as well as to update itself on the expectations and concerns of the people. FA staffs have maintained a critical balance in their relationships with such advocacy groups, avoiding any direct role in the campaigns organized by them. This strategy has helped FA to retain its CAR focus, while trying to reach out and actively engage with the ultimate beneficiaries of its work. FA's close ties with several community federations, including the offering of critical knowledge, has been received unwelcomingly by the more conservative officials of the MoFSC, but maintaining intellectual integrity in relationships with diverse stakeholders has enabled FA to retain its capacity to work with even the rival factions.

Ten years down the road, FA has a lot to share about how it moved through experimenting with different organizational modalities, not because there are ready to use success stories, but because there is a rich insight coming from multiple experiments. In the first year, we operated FA as a program initiative of an existing NGO as we hesitated to set up new $\mathrm{NGO}$ in the already crowded field of development NGOs in the country. At least at the beginning, this was also a pragmatic strategy for us to minimise the operating cost by sharing office space and utilities of a functioning NGO But as we accelerated our activity, we recognised that it would make more sense to register FA as an independent NGO, so we registered it separately. We had a governing board of seven people comprised only of those of us working in the organization and our close allies, as we wanted to keep the management and administration more organic and less costly in terms of coordination and governance. As our presence became more pronounced in Nepal's forest sector, after three years, we invited a University professor to chair the board. This marked the beginning of a more formal, externally visible NGO board. To expand the constituency of the organization we also increased the membership from initial 7 to the current over 40 
A key strategy we employed to make the organization less hierarchical than conventional NGOs is that the leadership remains rotational to avoid the emergence of a single dominating figure as is the case with many other NGOs in Nepal. For the first few years, we put excessive emphasis on teamwork by creating collective decision forums within the organization, but over time we realised that this proved too difficult and time-consuming for coordination. So we adopted a coordinating role at the center of management. We also invented a management team which shares power with the coordinator and actively supports him or her in providing leadership to the organization. The organization's work functions primarily through independent project leaders who are often specialists in the areas in which they work. Through this arrangement, the organisation has been able to host more than $5 \mathrm{PhDs}$ and senior researchers who enjoy a significant degree of freedom to design and undertake research and actions. Yet they all engage in collective learning and visioning through reflective meetings, sharing and deliberative practices.

So how does such a decentralised system of institution adopt the common values and approach of CAR? We emphasised discursive coordination rather than management control. This means holding meetings on specific agendas and issues, sharing critical insights and innovations, and enhancing social learning among the staff and professionals of FA.

In terms of financial management, we also experimented challenging strategies. FA does not normally provide monthly salary to senior staff - it ascertains a rate or overhead charge on the personnel fee. This way the institution does not take the burden of employing the staff, while the latter also feels that he or she has the autonomy to pursue the research and action. This applies even to the head of the organization - who is paid for 7-10 days of general administration and leadership works, and is free to work on the project of his or her interests. At times, we experimented with a full time coordinator of the organization but this did not work - as this arrangement contradicted with the usual ambition of the leader to act in actual agendas and projects, rather than remain a full time manager of the organization.

FA's system allows for remuneration generally on a par with the higher scales in the national NGO category. Unlike some prominent NGOs, we have not thought of extracting surplus but spent money for the project and staff. This does not mean every important job a staff member does at FA is paid - abou $25 \%$ of the work of senior staff is voluntary and is related to unfunded strategic work on creating counter-knowledge and critical policy engagement. While some people in Nepal differentiate their consulting or paid jobs from their volunteer social engagements, FA has taken the strategy of encouraging and capitalizing on the self-motivated strategic engagement of its senior professionals so as to raise the organization's profile and hence enhance its potential to influence the dominant system.

Despite efforts to become inclusive, the majority of our staffs have been male, non-dalits, and non-janajatis (ethnic groups). This was in part a criterion of staff efficiency that always remained critical to the competitive survival of the organization. This issue was pointed out by an external reviewer of the organization in 2010 (Lama 2011).

\section{Nurturing a New Breed of Critically}

\section{Engaged Action Researchers}

A major challenge we faced from the beginning, and to some extent till date, is to find professionals who have capacity to think against the current. We expanded the team by building on our own personal networks of people whom we knew well and had some level of confidence. We located potential members in 
different Universities in the UK and other collective learning is writing research and countries, and I personally happened to meet experiential reflections in various forms. Having with some of them and talk about the a strong writing culture was part of training possibility of working with FA in different for the new researchers but not everyone took occasions in its early years. We clearly explained it seriously. I particularly emphasized joint to everyone joining the organization at the senior authorship and we did not calculate much in level that we do not offer any monthly salary. terms of who did what and who gained what, We only provide the buffering opportunity of but adopted a generous strategy of sharing the certain days of work, with rates commensurate ownership, so as to establish new members in with experience and qualifications, and then the forestry sector. This created some tensions encouraged the persons to develop their own at different points specially when new and more projects and raise funds. This proved to be quite individually oriented researchers joined in. difficult. We realized that not all people are Through such processes, we were able to retrain equally positioned to develop and sell new even the technical foresters to see themselves as programs, so we began to have some form of critically engaged social researchers (Banjade role division among different groups of staff: 2012). new program development, field implementation, research, etc. There is now an emerging division of roles in project development and implementation depending on individual strengths and networking.

We always emphasize theoretically informed research and local action. This requires constant engagement with text as well as people. We always have some staff engaged in more conceptual research with others working on the ground on specific action issues, creating a combination that could together pool theoretical and empirical, political and technical, local and global knowledge on specific issues and then develop a robust knowledge to share with local stakeholders. In the process, we tried to make researchers activists, and activists researchers. We also launched some structured reading sessions but this depended on the enthusiasm of particular leaders. Those that have proved particularly useful are social learning, organizational learning, and action science. Different people read different strands used in research, writing, training, and informal sharing.

Holding reflective meetings out of the office premises proved quite fruitful, as it opened up more informal, open, and reflective moments for discussion and sharing. Another aspect of 
actor dialogues. Sometimes working through friends and colleagues offered a path into the broader institution of the government. As we grew, the government staff began to see that FA is serious in its agenda and work, and that it maintains a high level of professional integrity. Our expanding symbolic capital through networking with international community also made a difference in the eyes of the government officials. When we strengthened our ties with the federation of forest users, the audience of our research, this also helped to countervail techno-bureaucratic power.

After the government began to recognize the research and professional strengths from around 2007, they invited FA to relevant meetings, task forces and working groups. The major issue for FA is no longer being heard but about making our participation effective. The ball is now with FA itself to become even more proactive and contribute quality ideas.

Managing Knowledge Products and Communication

Documenting knowledge products has remained a key part of CAR. FA produces a wide range of knowledge products - from Journal of Forest and Livelihoods to policy briefs. These are meant to engage and inform a wide range of audience. By the end of 2011, FA has published 13 issues of Journal of Forest and Livelihoods, 15 issues of Hamro Ban Sampada, 16 policy discussion papers, 10 booklets and 31 policy briefs (Gurung 2011). Without developing these products, I think it would have been difficult for FA to have strong presence in the worlds of policy and knowledge. This has both epistemic and symbolic effects. Apart from such practitioner-oriented products, our research has also found its way into more academic and wider social science community. In doing so we have emphasized analysis of forest governance in Nepal through diverse social science angles.
At times, we were able to generate funds for such products, but in several occasions, we have pooled our own volunteer efforts to produce the journal and scientific outputs. Most of the discussion papers and policy briefs I wrote, and the journal issues I edited were purely voluntary efforts over and above the funding that was available for the field research portions of the work. This trend continues and several of the FA professionals put extra personal efforts to get the critical knowledge products delivered to the wider public.

Despite nurturing a new breed of researchers, we have consistently faced a capacity challenge. But this is a critical part of CAR. This is partly because we have not been able to retain the most competent people who are offered more competitive salary and benefits by international organizations working in Nepal.

Until recently, we did not focus on communication through mass media, as this requires a quite different set of communication skills than research and scientific writing. This has changed more recently, and we now have at least two media persons working with FA on a part time basis, guiding the entire team on how research products can and should be communicated in a way people can understand and benefit from.

Questioning the Funding Environment While Getting the Work Funded

Most cases of CAR practiced by FA researchers were or are operating within internationally funded development projects. Situated within the field of development means that such initiatives have to face the legacies of postWorld War II development - of western control over power, knowledge, and financing (Escobar 1995). This posed particular challenges for CAR actors, who have to confront not only the existing donor assumptions of linear planning and management but also the heightened material expectations of local stakeholders. 
Heavy reliance on external sponsorship means While funding access for generating counterthat there is still limited recognition of knowledge is largely limited, there is still another endogenous thinking and innovation, such as challenge FA faced in relation to accessible the CAR approach. There is usually a mismatch resources. Donors look for concrete and between funding cycles and temporal pathways verifiable developmental outcomes even when of innovation. Creating innovations in resource they are prepared to support CAR. The management and also facilitating critical pathways problem is not that CAR-like initiatives do not to innovation require societal investment and yield return on investment, but that their support, in order to have an impact. Yet, Nepal gestation period is longer, and need a different government has not earmarked funding for such evaluation methodology to ascertain the aid'soft development', given their emphasis on induced change than the conventional evaluation creating tangible development outcomes. In approaches. In several instances, funders have such situations, foreign aid continues to be a frustrated FA staff through their conventional key source of financing our work.

In the context of forestry, aid priorities are still governed by the colonial legacies of state-centric management continued primarily through bilateral forestry programs creating parallel structures. What is missing is a broad view of innovations in which research can be a function closely embedded within the process of development and change itself. Following the environmental turn of the development debate, and more recently the climate change crisis penetrating resource management approaches, the level of public funding (including international aid) has increased for environmental activities, but not necessarily to support CAR. The priorities are either delivery of services or technology transfer and are still guided by a positivist scientific ideology. Much international aid is handled and administered by international organizations (government, non-government, and bi- and multi-lateral projects), which are structured to filter critical voice counter-knowledge, and are instead conditioned to reproduce existing orders through the calculated paths of 'service delivery', 'policy support', and 'reaching the poor directly' without engaging local agents of change. In such situation, FA has to live in a paradox - to question the aid and also negotiate aid to fund its activities. cost-benefit approach to evaluation, focusing on what quantitative tools can measure, but ignoring more fundamental socioeconomic, cultural, and institutional outcomes of the initiatives (Giri et al. 2011). Contestations around the meaning, scope, and epistemology of evaluation therefore represent a key bottleneck in securing sponsorship for CAR approaches to natural resource management.

All this suggests that CAR oriented researchers and activists will have to work further to find ways to persuade the development donors to recognize the socioeconomic, cultural, and institutional outcomes as part of development. They also have an uphill struggle to influence public spending policies in developing countries to support CAR as a means to address questions of inclusion and democratization.

But the struggle to be done by critical action researchers is tough. I have myself encountered situations in which aid projects have approached me to respond to a particular development issue as a paid consultant (and work within the given Terms of Reference), in a clear attempt to coopt my civic standpoint. A colleague of mine who recently worked as a consultant to a bilateral development project later shared with me that he was asked to write what they wanted, and not what he found from the investigations. Another colleague also shared that his impact evaluation report was too critical to the project 
management, and hence the management did not want to publicize it. In many instances, FA has had to compromise its stance to secure funding, but it still has a good record of rejected consultancies that clearly targeted to undermine its critical stance on issues of public concerns.

Balancing Research, Advocacy, and Development Service Delivery

Organizing time and effort to balance research and action is particularly challenging, as the two functions often require diverse and competing sets of competencies, skills, and efforts, as well as institutional mechanisms.

The research part of CAR is sometimes seen as extractive and not relevant for local stakeholders and even policy makers. Likewise, the methodological frameworks of research still tend to carry the legacies of the positivist paradigm, with little thinking about how experiential insights can be tapped and interpreted. Another critical challenge experienced is when FA staff are seen as advocates of particular standpoints in specific governance debates, and not as independent researchers doing 'neutral research'. There is indeed a basic dilemma here - how can CAR researchers make a legitimate choice for their role in the spectrum between research and advocacy?

The key goal of FA CAR activities has been to improve the wellbeing of the peoples living in and around natural resources by engaging and empowering the local communities in the learning processes. While working at multiple scales is also important to CAR's success, direct collaboration with local communities has usually remained the cornerstone of CAR work. Unlike the experiences of service delivery projects (which offer some tangible services immediately) or traditional research projects (which do not engage people apart from collecting information), unique challenges have emerged pertaining to the CAR projects. First there is a scale perception gap between CAR facilitators and local communities. FA staff as CAR facilitators tend to see the problem of resource management and human wellbeing as a cross-scale phenomenon, and hence the need to analyze issues and generate evidence for meso-level and national policy deliberations. On the contrary, members of local communities tend to prioritize immediate fulfillment of needs and solution of the problems they are facing. Complex trajectories of change involving learning and collaboration are also not an immediate priority for those who have pressing livelihood needs. Efforts to generate research and address issues that are beyond these immediate concerns are thus particularly likely to meet with resistance.

Communities follow largely tacit ways of learning, and there is always some level of resistance to a research process that exposes unreflected assumptions. A senior staff colleague at FA, Banjade (2012) recalls his experience with some local communities in Nepal:

"Local people saw the researchers as NGO employees, among thousands of others, who they considered as having lucrative jobs and being interested only for 'dollar pachaune' (literally, 'digesting dollars coming from foreign sources'), rather than being committed to enhancing community wellbeing. Therefore, the researchers became victims of the dominant image of NGOs in Nepal, which are commonly blamed for (mis) using foreign support in the name of people."

This was largely animated by frustrations over the failures of the previous 50 years of the development industry in Nepal failures that strengthened social inequality (Metz 1995). For these reasons, developing relationships of trust with local actors has not always easy. Amidst 
such situations, forming task groups and engaging locally based facilitators has become a key strategy. Working with a select group of local 'change agents' or one or two group representatives from within the communities was found useful, but resulted in limited institutionalization of learning processes. As the planning and learning processes intensify through CAR based interventions, it is not straightforward to define, negotiate, and agree on who is going to participate in the actual action process, even when the process is being done at local level.

\section{Working Across Scales}

Two conceptions of cross-scale links are dominant in the resource governance literature: an institution and an adaptive system. Both of these are problematic, as they downplay the chaotic processes of interactions, as well as how agency interacts with systems and structures in the process of change or reproduction.

FA's experience reveals that the linking process has at least four axes and is not as structured an institution as some find it. We conceive crossscale linking processes as 'transactional flows' in terms of a) information flow, b) legitimating processes, c) value chain linkages, and d) exercise of power and counter-power. FA has made attempts to address multiple combinations of these diverse transactions, but practitioners report that success was much more limited than what they were able to achieve internally at local community levels.

All these processes are linked to whether or not the management of natural resources takes a system-wide view and provides an enabling environment for local innovations. A key gap in FA work is that it still fails to question and counteract the mentality of 'invent and diffuse across scales', rather than continuous innovations, which requires taking a learning based approach at all stages, and at all scales (from community to national and beyond) affecting the practice of natural resource management. The 'meso sphere,' between local and macro, has been found to be an important layer in the linking process; this more often takes the form of 'forums' than well-formed institutions. Though our work in most cases started at the community level, we evolved a greater realization of the need to work at the meso level and then link to the national level. This remained through the subsequent phases of the project. At times, FA has also been able to share its research-policy links by creating South Asia level forums of policy researchers (Paudel and Dhungana 2009).

\section{CONCLUSION}

This reflective story on the critically engaged action research experience of FA over the past 10 years demonstrates that the CAR approach can contribute to democratization of governance. This also shows a possible way forward for many NGOs that are now currently losing their sight as they are caught between advocacy, service delivery, and research roles as they strive to secure funding. This article makes the case that civil society activism should not be equated with pure advocacy of particular interests in a social segment; there is equally a role for critical action researchers who are capable of unravelling a broad spectrum of hegemonic exercise of power and even challenge the unquestioned acceptance of the order by the marginalized communities. Such an approach can become a flagship program of action for those seeking to contribute to change in more engaged way than traditional academic researchers do, in more intellectually reflective way than conventional rights activist do, and in more critical way than the technical researchers and development professionals approach the governance issues.

The attempts of FA have generated valuable evidence of the prospect of civic organizations to act as producers of counter-knowledge 
rather than reproducers and disseminators of hegemonic knowledge systems that sustain exclusion, domination and inequities. This is important in Nepal as many NGO actions are being colonized by external resources and knowledge that ignores or negates the perspective of change from below. The decade long experiment of FA, based on continued and determined practice of critical social science and production of counter-knowledge, also shows that it is possible for the dominant state and donor actors to become more interactive and collaborative in planning and governance processes (as found in the remarks of high level government officials on a CAR event reported in the previous section). This has particularly been effective when CAR researchers have collaborated with federations/associations of communities claiming rights over natural resources. The organizational aspect of CAR as practiced within FA reveals that the leadership has to take an adaptive approach to organization building, so as to sense and tap emerging political and intervention opportunities, and make CAR interventions relevant to the society.

This story also offers cautions on the formidable challenges one has to face while trying to organize critical and engaged action research, from building a competent team to confronting institutional powers and raising funds to sustain the activity. Sustaining the critical project is particularly challenging in the face of market fundamentalism, neo-positivism, unaccountable politics, and the degeneration of civic engagement culture. It is possible to think and act critically with impact. But new ways of understanding and measuring impact are necessary to enable CAR based innovations.

How can such community of critical action researchers proliferate in Nepal? We need a new breed of critically engaged researchers empowering disadvantaged actors and expanding deliberative spaces. They need to challenge the 'false consciousness' of the disadvantaged and unravel hidden power through carefully chosen facts and epistemological articulations. Fundamental rethinking is required in ways international development and environmental conservation businesses view civil society participation - as instrumental mobilisation of citizens. We should not transplant modernity from the west, but rather create critical, deliberative and reflective space for citizens to make informed choices.

While in part this is a question related to available political opportunities and economic incentives, I argue that it has more to do with the production of critical consciousness among the civic actors themselves. The development of such consciousness is not just a pedagogic process aided by some great trainers; it is also a process of change to bring crisis into the deep rooted cultural systems (Bourdieu 1998).

Therefore the CAR story of FA presented in this article is not an absolute success story without challenges. But what is clearly established is that civil society actors have to think and act differently to understand what changes they want to bring and how to bring them. Looking at the enormous challenges we faced in helping policy development in community based forestry systems in Nepal, serious doubts can be cast on many claims of change and transformations made by government and international organizations (including INGOs, multilateral and bilateral programs). Inclusive development cannot occur through upscaling service delivery within the current structure and systems (as emphasised by many donor and government programs), nor through pure interests based advocacy and campaigns alone (as emphasized by rights activists and associations). Nepal's future development and environmental sustainability reside on the degree to which critical, learning oriented civic actors emerge and engage with different stakeholders in different domains of governance. 


\section{REFERENCES}

Banjade, M. and Ojha, H. 2005. Facilitating Deliberative Governance: Innovations from Nepal's Community Forestry - A Case of Karmapunaya. The Forestry Chronicle, 81(3): 403-408.

Banjade, M. R. 2012. Learning to Improve Livelihoods: Applying Adaptive Collaborative Approach to Forest Governance in Nepal. In: H. Ojha, A. Hall and V. Rasheed Sulaiman (Eds), Adaptive Collaborative Approaches in Natural Resource Governance: Rethinking Participation, Learning and Innovation (pp 216-256). Oxon and New York: Routlage

Bourdieu, P. 1998. Practical Reason: On The theory of Action. Cambridge: Polity.

Bourdieu, P., Chamboredon, J.C. and Passeron, J.C. 1991. The craft of Sociology: Epistemological Preliminaries. Berlin, New York : Walter de Gruyter.

Cameron, J. 1998. Development Thought and Discourse Analysis: A Case Study of Nepal. In: K. Bahadur and M. L. Lama (Ed.), New Perspectives on India-Nepal Relations. New Delhi: Har-Anand Publications.

Dhital, N., Paudel, K.P. and Ojha, H. 2002. Inventory of Community Forests in Nepal: Problems and Opportunities. Kathmandu: ForestAction Nepal and LFP.

Eckholm, E. P. 1976. Losing Ground: Environmental Stress and World Food Prospects. New York: W W Norton.

Escobar, A. 1995. Encountering Development: the Making and Unmaking of the Third World. Princeton: NJ, Princeton University Press.

FA. 2009. Concerns and Suggestions on the Community Forestry Impact Evaluation Study: A Letter Submitted to Ministry of Forest and Soil Conservation on December 29, 2009. Kathmandu: ForestAction Nepal.

FA. 2012. Ban Chautari: A Multi-stakeholder Dialogue on Forest Policy Issues. Annual Review Meeting Note 30th December, 2011 Indreni Complex, Kathmandu. Kathmandu: ForestAction Nepal.

Fisher, R. 2012. Learning through Action: Reflections on Action Research in Natural Resource Management. In: H. Ojha, A. Hall and V. Rasheed Sulaiman (Eds), Adaptive Collaborative Approaches in Natural Resource Governance:Retbinking Participation, Learning and Innovation (pp 257-286). Oxon and New York: Routlage.

Giri, K., Uprety, D., Ojha, H. and Banjade, M.R. 2011 What Does Research into Use Actually Mean: A View from the Reality of Practice. Draft Discussion Paper. Kathmandu: ForestAction Nepal.

Gramsci, A. 1990. Culture and Ideological Hegemony. In: J. C. Alexander and S. Seidman, Culture and society: Contemporary debates (Ed.). Cambridge: Cambrdige University press.
Gurung, N. 2011. Critical Action Research at ForestAction Some Notes and Reflections. Kathmandu: ForestAction Nepal.

Habermas, J. 1970. On Systematically Distorted Communication. Inquiry, 13(1-4): 205-218.

Hull, J., Ojha, H. and Paudel, K.P. 2010. Forest Inventory in Nepal - Technical Power or Social Empowerment? In: A. Lawrence, Taking Stock of Nature: Participator Biodiversity Assessment for Policy, Planning and Practice (pp 165 184). Cambrdige: Cambridge University Press.

Karna, B. K., Shivakoti, G.P. and Webb, E.L. 2010. Resilience of Community Forestry Under Conditions of Armed Conflict in Nepal. Environmental Conservation, 37(2) 201-209.

Khatri, D. B, D. BK and N. S. Paudel. 2012. Consolidating Multi-Stakeholder Process in Forest Policy Decisions Through Ban Chautari (Forest Dialogue) in Nepal: Fina Report. Kathmandu: ForestAction Nepal, Nepal Foresters' Association, Federation of Community Forestry User Nepal and Asmita Nepal.

Lama, M. S. 2011. A Decade of ForestAction Nepal (2001 2010): A Review Report. Kathmandu: ForestAction Nepal.

Lewin, K. 1951. Field theory in Social Science: selected theoretical papers (Edited by Dorwin Cartwright.).

Luintel, H. 2006. Do Civil Society Organizations Promote Equity in Community Forestry? A Reflection from Nepal's Experiences. In: S. Mahanth, J. Fox, M. Nurse and L. Mclees (Eds.), Hanging on the Balance: Equity in Community-Based Natural Resource Management in Asia, (pp 122142). East-West Centre and RECOFTC, Bangkok.

McDougall, C., Ojha, H., Pandey, R.K., Banjade, M.R. and Pandit, B.H. 2007. Enhancing Adaptiveness and Collaboration in Community Forestry in Nepal: Reflections from Par ticipatory Action Research. Adaptive Collaborative Management of Community Forests in Asia: 52.

McDougall, C., Pandit, B.H., Banjade, M.R., Paudel, K.P, Ojha, H. Maharjan, M., Rana, S., Bhattarai, T. an Dangol, S. 2009. Facilitating Forests of Learning: Enabling an Adaptive Collaborative Approach in Community Forest User Groups, a Guidebook Bogor, Indonesia, Center for International Forestry Research.

Metz, J. J. 1995. Development in Nepal: Investment in the Status quo. GeoJournal, 35:175-184.

Oiha, H. 2002. A Critical Assessment of Scientific and Political Aspects of the Issue of Community Forest Inventory in Nepal. Kathmandu: ForestAction Nepal.

Ojha, H. 2006. Techno-Bureuacratic Doxa and the Challenges of Deliebrative Governance - The Case of Community Forestry Policy and Practice in Nepal. Policy and Society, 25(2): 131-175. 
Ojha, H. 2009. Civic Engagement and Deliberative Governance: The Case of Community Forest Users' Federation, Nepal. Studies in Nepalese History and Society (SINHAS), 4(2): 303-334.

Ojha, H. R. 2008. Reframing Governance: Understanding Deliberative Politics in Nepal's Terai Forestry. New Delhi: Adroit Publishers.

Ojha, H. R., Paudel, N.S., Banjade, M.R., McDougall, C. and Cameron, J. 2010. The Deliberative Scientist: Integrating Science and Politics in Forest Resource Governance in Nepal. In: L. German, J. J. Ramisch and R. Verma (Eds.). Beyond the Biophysical: Knowledge, Culture, and Politics in Agriculture and Natural Resource Management (Eds). Dordrecht, Hiedelberg, London and New York: Springer: 167-191.

Ojha, H. R., Timsina, N., Kumar, C., Belcher, B. and Banjade, M. 2008. Communities, Forests and Governance: Policy and Institutional Innovations from Nepal. India: Adroit Publishers.

Ojha, H., Timsina, N. and Khanal, D. 2007. How are Forest Policy Decisions Made in Nepal? Journal of Forest and Livelibood, 6(1): 1-16.

Paudel, K. P. and Ojha, H.R. 2008. Contested Knowledge and Reconciliation in Nepal'ÿs Community Forestry: A Case of Forest Inventory Policy. In: H. R. Ojha, N. P.
Timsina, R. B. Chhetri and K. P. Paudel (Eds.), Knoweldge Systems and Natural Resouces: Management, Institutions and Policy in Nepal. Delhi, Cambridge University Press India Limited and IDRC

Paudel, N. and Ojha, H. 2011. Influencing forest policy process: Combining research with activism. Paper presented at national conference on Expert and Policy Process: Concepts, Experience and Challenges (September 25, 2011). Kathmandu, Nepal, Nepal Policy Research Network (NPRN).

Paudel, N. S. and Dhungana, H. 2009. Linking Research and Policy: Emerging Issues and Innovations in South Asia. South Asia Regional Workshop, 6-7th August 2009

Shrestha, C. H. and Adhikari, R. 2010 Antipolitics and Counterpolitics in Nepal,Äôs Civil Society: The Case of Nepal,Ä̂̂s Citizens, Ä̂̂ Movement. Voluntas: International Nepal,Aôs Citizens,Aô Movement. Voluntas: International 316.

Tarrow, S. 1996. States and opportunities: The Political Structuring of Social Movements. Comparative Perspectives on Social Movements, 41-61.

Timsina, N.P., Luintel, H., Bhandari, K. and Thapaliya, A. 2004. Action and Learning: An Approach for Facilitating a Change in Knowledge and Power Relationship in Community Forestry. Journal of Forest and Livelihood, 3(1):1-8.

Two laws are noteworthy here - Forest Act 1961 and Forest Protection Special Act 1967. The latter even authorized forest guards to shoot people using forest illegally.

In the decades of $60 \mathrm{~s}$ and $70 \mathrm{~s}$, Nepal was projected as a site of Himalayan degradation, and this attracted tremendous international attention. During the early 1980s, Nepal's mountains were perceived as a site of tremendous international attention. During the early $1980 \mathrm{~s}$, Nepal's mountains were perceived as a site of
environmental and livelihoods crisis - deforestation and soil erosion were affecting water flows and livelihood environmental and livelihoods crisis - deforestation and soil erosion
resources base locally and beyond (Eckholm 1976; Cameron 1998)

iii Personal communication, Dr Naya Sharma Paudel, January 31, 2012, Kathmandu, Nepal. 